\title{
토종닭 농장주 및 가공업자가 바라본 토종닭 산업의 미래 방향
}

\author{
윤지원 ${ }^{1} \cdot$ 이현정 ${ }^{2} \cdot$ 남기창 $^{3} \cdot$ 조철훈 ${ }^{2,4^{+}}$ \\ ${ }^{1}$ 서울대학교 농생명공학부 학생, ${ }^{2}$ 서울대학교 식품바이오융합연구소 연구원, \\ ${ }^{3}$ 순천대학교 동물자원과학과 교수, ${ }^{4}$ 서울대학교 농생명공학부 교수
}

\section{Future Business Direction of Korean Native Chicken: Farmer and Processor Perspectives}

\author{
Ji Won Yoon', Hyun Jung Lee ${ }^{2}$, Ki Chang $\mathrm{Nam}^{3}$ and Cheorun $\mathrm{Jo}^{2,4^{+}}$ \\ ${ }^{I}$ Student, Department of Agricultural Biotechnology, Seoul National University, Seoul 08826, Republic of Korea \\ ${ }^{2}$ Researcher, Center for Food and Bioconvergence, Seoul National University, Seoul 08826, Republic of Korea \\ ${ }^{3}$ Professor, Department of Animal Science and Technology, Sunchon National University, Suncheon 57922, Republic of Korea \\ ${ }^{4}$ Professor, Department of Agricultural Biotechnology, Seoul National University, Seoul 08826, Republic of Korea
}

\begin{abstract}
The aim of this study was to investigate the difficulties that Korean farmers and processors currently experience with respect to the market for Korean native chicken (KNC). This study also provides suggestions by which they can overcome these difficulties. In all, sixty-nine farmers and sixty-two processors participated in our investigation, which addressed 1) the current difficulties that $\mathrm{KNC}$ farmers face, 2) the current importance-satisfaction measures among $\mathrm{KNC}$ farmers and processors, and 3) the future direction of the KNC market: farmer and processor opinions. The respondents stated that the limited number of sales stores was the most difficult market condition they faced in raising $\mathrm{KNC}$, followed by feed cost, animal disease, and poor production environment. Regarding issues of importance and satisfaction, origin in raising step and slaughtering in the processing and distribution step were considered the areas most in urgent need of improvement, given farmers' and processors' high levels of dissatisfaction with these. Both the free-range farming system and the concept of animal welfare are growing in importance, given consumers' interests in these areas. As to opinions on the direction of KNC development, menu development was cited as most important, followed by public advertisement, accessibilities, business aid, and breed development. Consequently, the results show that well-organized support from both the government and related industries is needed, as chicken farmers and processors cannot resolve certain limitations inherent in the KNC industry on their own.
\end{abstract}

(Key words: Korean native chicken, farmer, processor, direction)

\section{INTRODUCTION}

As Korean per capita income increases, its per capita consumption of animal products also rapidly increases (MAFRA, 2017a; Nam et al., 2010). In particular, per capita chicken meat consumption was $13.8 \mathrm{~kg}$ in 2016-a number twice that seen in 2000 (MAFRA, 2017a). This phenomenon has also been seen in other Asian countries, given that chicken products offer certain advantages relative to other meat products (i.e., lower fat and cholesterol content, easy to handle, and subject to fewer religious barriers) (Jayasena et al., 2013; Kim et al., 2018a). Thus, there is no doubt that, in the near future, worldwide chicken production and consumption will increase on account of increased demand in Asia, a continent that is increasingly becoming more industrialized (Heinrich Böll Foundation and Friends of the Earth Europe, 2014).

Approximately $90 \%$ of chicken consumed in Korea comprises foreign broiler breeds (Jung et al., 2011), with Korean native chicken (KNC) having comparatively lower levels of commercial performance. Therefore, since the 1990s, the National Institute of Animal Science has been developing a

${ }^{+}$To whom correspondence should be addressed : cheorun@snu.ac.kr 
KNC breeding and raising system (Kim et al., 2010a; 2010b). As a result of the Institute's initiatives, the availability of $\mathrm{KNC}$ has increased, and its texture and flavor have improved. KNC offers a "chewiness" that Korean consumers prefer (Jung et al., 2011; Jayasena et al., 2013). Furthermore, it has a strong flavor on account of its large quantities of tasterelated compounds (e.g., inosine 5'-monophosphate, glutamic acid, reducing sugar, linoleic acid, arachidonic acid, and docosahexaenoic acid) (Ahn and Park, 2002; Choe et al., 2010; Jayasena et al., 2014). Additionally, relative to commercial broilers, KNC also possesses greater amounts of bioactive compounds (e.g., carnosine, anserine, carnitine, and creatine) (Jin et al., 2017); these factors may also have effects on consumers' buying decisions.

When looking to increase KNC's market share, due consideration should be made for developments in $\mathrm{KNC}$ availability, as well as the real-life practical difficulties that farmers and processors experience. However, to date, there has been no report on the current perspectives of $\mathrm{KNC}$ farmers and processors in terms of production and/or distribution-perspectives which may very well differ from those of consumers. Therefore, the objective of this study was to investigate the opinions of $\mathrm{KNC}$ farmers and processors, as well as the challenges they face, with the endpoint of providing suggestions and possible solutions by which they can overcome the current limitations inherent in the $\mathrm{KNC}$ market.

\section{MATERIALS AND METHODS}

\section{Subjects}

We designed and implemented our questionnaire-based investigation through the company Research and Research (Seoul, Korea), and it took place between November 17 and 23, 2014, technically supported by Korean Native Chicken Association. Quota sampling was used to extract subjects based on their occupation and age. A total of 131 individuals (69 farmers and 62 processors) took part in the investigation, which made use of the $95 \%$ confidence and $4.48 \%$ standard error level. Table 1 provides demographic profile data on the respondents.
Table 1. Demographic characteristics of the respondents

\begin{tabular}{|c|c|}
\hline Characteristics & Number \\
\hline \multicolumn{2}{|l|}{ Occupation (number) } \\
\hline Chicken farmers & 69 \\
\hline Processors & 62 \\
\hline Total & 131 \\
\hline \multicolumn{2}{|l|}{ Scale of raising chicken (\%) } \\
\hline$\sim 300$ & 10.4 \\
\hline $1,000 \sim 5,000$ & 10.4 \\
\hline $5,000 \sim 10,000$ & 7.8 \\
\hline $10,000 \sim$ & 71.4 \\
\hline \multicolumn{2}{|l|}{ Breeds raised $(\%)$} \\
\hline Korean native chicken & 81.7 \\
\hline Korean native chicken and broiler & 18.3 \\
\hline \multicolumn{2}{|l|}{ Annual sales (in millions won) (\%) } \\
\hline$\sim 5$ & 10.8 \\
\hline $5 \sim 10$ & 5.4 \\
\hline $10 \sim 20$ & 10.8 \\
\hline $20 \sim 30$ & 19.4 \\
\hline $30 \sim$ & 53.8 \\
\hline \multicolumn{2}{|l|}{ Age (\%) } \\
\hline $20 \mathrm{~s} \sim 40 \mathrm{~s}$ & 35.9 \\
\hline $50 \mathrm{~s}$ & 38.9 \\
\hline $60 \mathrm{~s}$ & 25.2 \\
\hline \multicolumn{2}{|l|}{ Place of residence $(\%)$} \\
\hline Seoul & 6.1 \\
\hline Gyeonggi $\cdot$ Incheon & 18.3 \\
\hline Chungcheong & 30.5 \\
\hline Jeolla & 36.6 \\
\hline Gyeongsang & 8.4 \\
\hline Total & 100 \\
\hline
\end{tabular}

\section{Questionnaire}

The questionnaire was created on the basis of the literature and discussions with experts, to collect information on the opinions of $\mathrm{KNC}$ farmers and processors. The questionnaire consisted of three sections: 1) the current difficulties that 
KNC farmers face, 2) the current importance-satisfaction measures among $\mathrm{KNC}$ farmers and processors, and 3) the future direction of the $\mathrm{KNC}$ market: farmer and processor opinions. The items addressed in each section were also selected on the basis of the literature and discussion with experts. For each of sections 1 and 2, the respondents scored each item using a seven-point Likert scale ranging from 1 (Strongly disagree) to 7 (Strongly agree); for section 3, they scored each item using a nine-point Likert scale ranging from 1 (Strongly disagree) to 9 (Strongly agree). The actual questionnaire items were as follows.

1) What is the hardest part of raising Korean native chickens?

2-1) How important are the following Korean native chicken issues?

2-2) Currently, how satisfied are consumers with the following Korean native chicken issues?

3) What is needed to revitalize the Korean native chicken market?

\section{Statistical Analysis}

The collected data were analyzed using SPSS 21.0 for Windows (IBM, Chicago, IL, USA). Based on the average values, for the items listed in Table 3 , importance-performance analysis was undertaken to analyze the correlation between importance and satisfaction.

\section{RESULTS AND DISCUSSION}

\section{The Current Difficulties that KNC Farmers Face}

More than $50 \%$ of the respondents cited a limited number of sales stores as the greatest difficulty in raising $\mathrm{KNC}$; this was followed by feed cost, animal disease, and poor production environment (Table 2). Most of these challenges can scarcely be overcome by $\mathrm{KNC}$ farmers alone, in the absence of outside assistance.

In Korea, approximately $90 \%$ of chickens -including KNC - are sold through large distribution companies (KREI, 2013). In other words, the establishment of additional sales stores and outlets could be greatly affected by the current distribution system. For this reason, changes in this area may require government and/or industry intervention that supports
Table 2. The difficulties that chicken farmers $(n=69)$ face in raising Korean native chicken

\begin{tabular}{lc}
\hline \multicolumn{1}{c}{ Items } & $\%$ \\
\hline Limited number of sales stores & 50.72 \\
Feed cost & 24.64 \\
Animal disease & 10.15 \\
Poor production environment & 10.14 \\
Other & 2.90 \\
No answer & 1.45 \\
\hline \multicolumn{2}{c}{ Total } \\
\hline
\end{tabular}

the diversification of the chicken meat distribution system. Meanwhile, online sales has been suggested as a means of increasing consumer accessibility to $\mathrm{KNC}$ : online sales would allow consumers to purchase $\mathrm{KNC}$ directly from farms, while concurrently increasing the reliability of the origin at the raising stage (Table 3). Furthermore, online sales could satisfy consumer demand for lower KNC prices $(23.5 \%$, data not shown) by reducing its distribution cost. The distribution cost accounts for approximately $52.1 \%$ of KNC's market price (KREI, 2013), with consumers paying an additional $1.6 \%$ in expenses per year on account of increased distribution costs. This rising cost, in turn, reduces the income of KNC farms by approximately $0.5 \%$ per year (KREI, 2013). Consequently, online sales could be beneficial for consumers and $\mathrm{KNC}$ farmers alike. However, it may be difficult for $\mathrm{KNC}$ farmers to use an online sales system, as most of them $(64.1 \%)$ are over 50 years of age (Table 1). Under such circumstances, educational support with regard to setting up and using new systems should be provided.

High feed costs (a challenge cited by $24.64 \%$ of farmers) incurred by the longer $\mathrm{KNC}$ raising period (relative to that of broilers) has led to ongoing economic losses among $\mathrm{KNC}$ farmers (Choe et al., 2010) (Table 2). Moreover, the market price of corn -the main ingredient in animal feed-has been increasing recently (Jung et al., 2012). This may result in an increase in not only feed costs, but also in the market price of livestock products. Consequently, this problem can be resolved either by reducing the $\mathrm{KNC}$ raising period and/or using corn substitutes in animal feed. In any case, scientific 
Table 3. Levels of importance and satisfaction that farmers and processors assign to various issues when raising, processing, and distributing Korean native chicken

\begin{tabular}{|c|c|c|c|c|}
\hline \multirow{2}{*}{ Items } & \multicolumn{2}{|c|}{ Farmers } & \multicolumn{2}{|c|}{ Processors } \\
\hline & Importance $(\%)$ & Satisfaction (\%) & Importance $(\%)$ & Satisfaction $(\%)$ \\
\hline \multicolumn{5}{|l|}{ Raising step } \\
\hline Origin & 93.00 & 83.57 & 92.47 & 82.53 \\
\hline $\mathrm{HACCP}^{1}$ approval & 76.98 & 74.59 & 79.57 & 71.77 \\
\hline $\begin{array}{l}\text { Certification of } \\
\text { eco-friendliness }\end{array}$ & 74.51 & 72.05 & 75.00 & 65.90 \\
\hline Free-range farming & 61.84 & 67.01 & 61.83 & 56.45 \\
\hline Animal welfare & 61.98 & 64.47 & 64.73 & 49.58 \\
\hline Market age & 71.01 & 68.44 & 70.16 & 52.87 \\
\hline Market weight & 72.71 & 70.37 & 70.43 & 54.78 \\
\hline \multicolumn{5}{|c|}{ Processing/distribution step } \\
\hline Safety & 81.88 & 78.08 & 91.13 & 76.25 \\
\hline Packaging & 73.67 & 73.14 & 81.72 & 73.22 \\
\hline Branding & 68.12 & 70.84 & 65.32 & 67.24 \\
\hline Native certification & 82.08 & 75.45 & 77.96 & 63.22 \\
\hline Slaughtering & 76.81 & 71.17 & 74.73 & 55.60 \\
\hline
\end{tabular}

${ }^{1}$ HACCP: Hazard Analysis Critical Control Point system.

research and investment are required.

The occurrence of animal disease-especially of avian influenza (AI) - was the third most frequently cited challenge in raising $\mathrm{KNC}$ (10.15\% of farmers). Whenever an outbreak of AI occurred, all the chickens were stamped out, and consumer purchases of chicken declined considerably (KREI, 2013). As a result, the price of chicken decreased in spite of its small production scale, and farmers sustained critical economic damage. Under such circumstances, efforts for the prevention of animal diseases are needed. Scientific research - such as that on the quality and efficacy of vaccines - should be conducted with support from the government or a private research entity, for example.

Meanwhile, the poor production environment of chicken farms - which could lead directly to the occurrence of animal disease-was another difficulty, cited by $10.14 \%$ of farmers (Table 2). However, in the absence of outside support, farmers may find it difficult to improve those production environments, given the incidental costs involved. To alle- viate this problem, the government, related industries, or both should support reconstruction projects on old farms.

\section{The Current Importance-Satisfaction Measures among KNC Farmers and Processors}

We investigated the current importance and satisfaction measures of $\mathrm{KNC}$ farmers and processors with respect to issues encountered while raising and distributing KNC (Table 3 ). Based on average values, all issues were scored in terms of these two dimensions, giving rise to four categoriesnamely, high importance, high satisfaction (HIHS); high importance, low satisfaction (HILS); low importance, high satisfaction (LIHS); and low importance, low satisfaction (LILS) (Fig. 1). These issues were then categorized in terms of these four categories.

In raising $\mathrm{KNC}$, the origin, $\mathrm{HACCP}$ approval, and certification of eco-friendliness were categorized as HIHS, while free-range raising, animal welfare, market age, and market weight were categorized as LILS. These categorizations held 

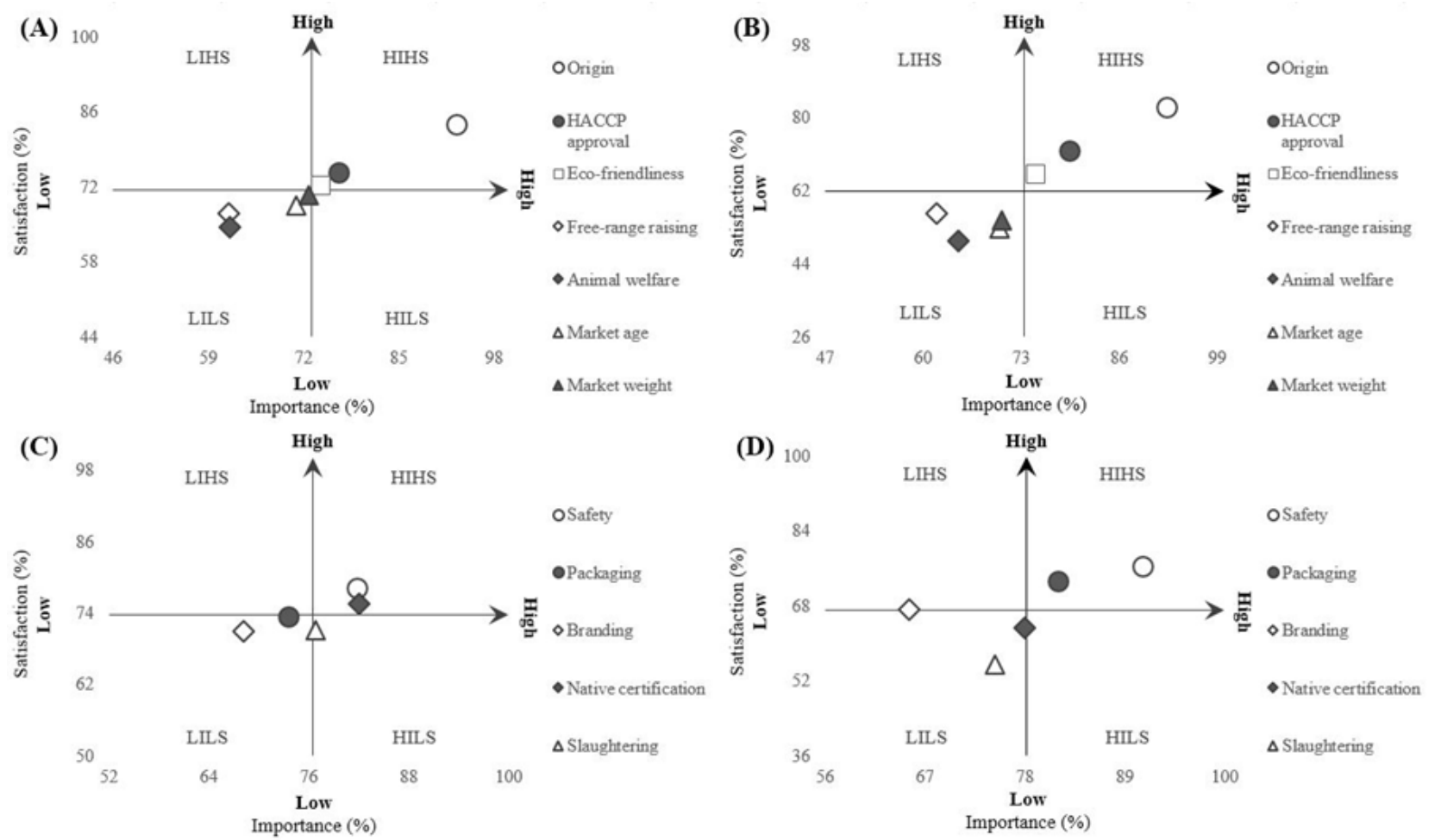

Fig. 1. Classifications along the importance - satisfaction dimensions of certain issues inherent in producing and distributing Korean native chicken.

(A) farmers in the raising step; (B) processors in the raising step; (C) farmers in the distribution step; (D) processors in the distribution step. HIHS: high importance, high satisfaction; HILS: high importance, low satisfaction; LIHS: low importance, high satisfaction; LILS: low importance, low satisfaction.

regardless of respondents' occupation (Figs. 1(A) and 1(B)). On the other hand, in distributing $\mathrm{KNC}$, classifications were found to differ between farmers and processors, except for items pertaining to safety (HIHS) (Figs. 1(C) and 1(D)). For farmers, native certification was an HIHS item, whereas packaging and branding were LILS items; slaughtering, on the other hand, was HILS. For processors, packaging and branding were HIHS and LIHS items, respectively, and native certification and slaughtering were both LILS items. Although farmers and processors participate in both raising and distribution, they have different roles and levels of awareness in each of these steps. Additionally, each issue differentially relates to the steps that lead up to $\mathrm{KNC}$ sale. For example, native certification relates to $\mathrm{KNC}$ origin in the raising step, while both packaging and branding closely relate to product guarantees in the processing and distribution step. Therefore, differences in importance and satisfaction may originate from different levels of recognition between the two occupational groupings.

Items within the HIHS and LIHS categories need to maintain their current conditions, as they currently satisfy respondents with respect to the importance they place on raising and distributing $\mathrm{KNC}$. In contrast, items within the HILS category require urgent improvement. For example, slaughtering should be conducted with government permission, given the need to adhere to the particulars of the Livestock Products Sanitary Control Act of Korea (MFDS, 2018). KNC derived from illegal slaughtering has been found in numerous local restaurants, and this illegal activity could spread animal disease and lead to outbreaks of food poisoning (APQA, 2008; MAFRA, 2017b). It is therefore essential that the government tighten its supervision and regulation of slaughtering. Those items within the LILS category are not currently considered as "serious" as those in the other categories; nonetheless, some LILS items could potentially forecast increases in $\mathrm{KNC}$ consumption. In particular, free- 
range farming and animal welfare are issues growing in importance among consumers, who are generally taking a greater interest in the issues of animal welfare and public health (Font-i-Furnols and Guerrero, 2014). However, on a farm, animal welfare relates directly to efficiency and production (McInerney, 2004); for this reason, it would be difficult to immediately apply the concept of animal welfare to farm-site operations. Therefore, again, the government and/or related industries should help promote animal welfare on farms, by providing encouragement and assistance. In addition, important animal welfare concepts in the context of Korea should be established after thorough investigation and critical discussion.

\section{The Future Direction of the KNC Market: Farmer and Processor Opinions}

In terms of growing the $\mathrm{KNC}$ market, $60.87 \%$ of farmers and $59.68 \%$ of processors considered menu development the most important item; this was followed by public advertisements (27.54\% and 27.42\%), accessibility (7.25\% and $6.45 \%)$, business aid (2.89\% and $4.84 \%)$, and breed development $(1.45 \%$ and $1.61 \%)$ (Table 4$)$.

There are only few cooking methods for which $\mathrm{KNC}$ is appropriate, given its flavor and texture characteristics; generally, $\mathrm{KNC}$ is most appropriate for stew cuisine (Han et al., 1996; Jayasena et al., 2013) such as Baeksuk, Samgyetang, or Dakbokumtang. Therefore, new menu developmentespecially that which targets younger generations - is needed,

Table 4. Farmers' and processors' opinions regarding where efforts to promote the Korean native chicken market should be directed

\begin{tabular}{ccc}
\hline \hline \multirow{2}{*}{ Items } & \multicolumn{2}{c}{ Occupation } \\
\cline { 2 - 3 } & Farmers (\%) & Processors (\%) \\
\hline Menu development & 60.87 & 59.68 \\
Public advertisement & 27.54 & 27.42 \\
Accessibility & 7.25 & 6.45 \\
Business aid & 2.89 & 4.84 \\
Breed development & 1.45 & 1.61 \\
\hline Total & 100 & 100 \\
\hline
\end{tabular}

and it will require collaboration between professional menu development institutes and experts who possess comprehensive knowledge of $\mathrm{KNC}$ and its advantages, and who also understand how important the promotion and diversification of chicken consumption are to the industry. In this respect, recent studies on foreign certification systems (Kim et al., 2018b) and KNC recipe-development trials (Kim, 2018), as well as similar future research, offer some promise.

Additionally, Troy and Kerry (2010) point out that public advertisements will help pique the interest of consumers. $27.5 \%$ of consumers agreed to the necessity of public advertisements in developing the $\mathrm{KNC}$ industry and in facilitating and promoting $\mathrm{KNC}$ market accessibility (data not shown). This finding aligns with the results of the current study from farmers and processors. Consequently, the government and related industries should plan, either separately or in collaboration, to undertake effective and continuous public relations strategies with regard to $\mathrm{KNC}$.

\section{CONCLUSION}

By investigating the limitations and goals inherent in raising and producing $\mathrm{KNC}-$ which are known by considering data on farmers' and processors' viewpoints - it is clear that $\mathrm{KNC}$ development requires organized support from the government and related industries. In addition, all parties that have a stake in the KNC market should direct efforts toward the issues of animal welfare and public health, to differentiate $\mathrm{KNC}$ from commercial broilers.

\section{ACKNOWLEDGMENTS}

This work was carried out with the support of "Golden Seed Project (Project No. PJ012822), Korean Institute of Planning \& Evaluation for Technology in Food, Agriculture, Forestry \& Fisheries.

\section{REFERENCES}

Ahn DH, Park SY 2002 Studies on components related to taste such as free amino acids and nucleotides in Korean 
native chicken meat. J Korean Soc Food Sci Nutr 31(4):547-552.

Animal and Plant Quarantine Agency 2008 Results of special crackdowns on illegal slaughterhouses such as traditional markets across the country.

Choe JH, Nam KC, Jung S, Kim B, Yun HJ, Jo C 2010 Differences in the quality characteristics between commercial Korean native chickens and broilers. Korean J Food Sci An 30(1):13-19.

Font-i-Furnols M, Guerrero L 2014 Consumer preference, behavior and perception about meat and meat products: An overview. Meat Sci 98(3):361-371.

Han JS, Han GP, Kim JS, Kim MH 1996 A study for the mechanical and sensory characteristics of chickens by cooking methods-For the focus on native chicken-. J East Asian Soc Diet Life 6(3):307-316.

Heinrich Böll Foundation and Friends of the Earth Europe 2014 Meat Atlas.

Jayasena DD, Jung S, Kim HJ, Bae YS, Yong HI, Lee JH, Kim JG, Jo C 2013 Comparison of quality traits of meat from Korean native chickens and broilers used in two different traditional Korean cuisines. Asian Australas J Anim Sci 26(7):1038-1046.

Jayasena DD, Kim SH, Lee HJ, Jung S, Lee JH, Park HB, Jo C 2014 Comparison of the amounts of taste-related compounds in raw and cooked meats from broilers and Korean native chickens. Poult Sci 93(12):3163-3170.

Jin S, Jayasena DD, Jo C, Lee JH 2017 The breeding history and commercial development of the Korean native chicken. World Poult Sci J 73(1):163-174.

Jung B, Mitchell RD, Batal AB 2012 Evaluation of the use of feeding distillers dried grains with solubles in combination with canola meal on broiler performance and carcass characteristics. J Appl Poult Res 21(4):776-787.

Jung Y, Jeon HJ, Jung S, Choe JH, Lee JH, Heo KN, Kang BS, Jo C 2011 Comparison of quality traits of thigh meat from Korean native chickens and broilers. Korean J Food Sci An 31(5):684-692.
Kim HC, Choe J, Nam KC, Jung S, Jo C 2018a Productivity and meat quality of the new crossbred Korean nativce chickens compared with commercial breeds. Korean J Poult Sci 45(2):125-135.

Kim HK, Hong EC, Kang BS, Park MN, Chae HS, Bang HT, Seo BY, Choo HJ, Na SH, Seo OS, Hwangbo J 2010a Effect of crossbred Korean native ducks on the retail cut yield, meat quality, and sensory evaluation of duck meats. Korean J Poult Sci 37(4):423-431.

Kim HK, Hong EC, Kang BS, Park MN, Seo BY, Choo HJ, $\mathrm{Na}$ SH, Bang HT, Seo OS, Hwangbo J 2010b Effect of crossbreeding of Korean native duck and broiler ducks on performance and carcass yield. Korean J Poult Sci 37(3):229-235.

Kim JK 2018 Todaktodak restaurant, recipe book for Korean native chicken dish. http://www.amnews.co.kr/news/article View.html?idxno=25983. Accessed at October 27, 2018.

Kim S, Lee D, Moon J 2018b A study on regional native chicken and certification system in France - Focusing on $\mathrm{Al}$ sace, Bresse region. Korean J Poult Sci 45(1):41-51.

Korea Rural Economic Institute 2013 Agricultural Outlook.

McInerney J 2004 Animal welfare, economics and policy. Report on a study undertaken for the Farm \& Animal Health Economics Division of Defra.

Ministry of Agriculture, Food and Rural Affairs 2017a Major statistics data for food, agriculture, forestry and fisheries.

Ministry of Agriculture, Food and Rural Affairs 2017b Trend of AI outbreak and status of quarantine promotion.

Ministry of Food and Drug Safety 2018 Livestock product sanitary control act. Act No. 14957.

Nam KC, Jo C, Lee M 2010 Meat products and consumption culture in the East. Meat Sci 86(1):95-102.

Troy DJ, Kerry JP 2010 Consumer perception and the role of science in the meat industry. Meat Sci 86(1):214-226.

Received Dec. 19, 2018, Revised Mar. 10, 2019, Accepted Mar. 11,2019 
